\title{
ANALYSIS OF PROTEINS FROM MEMBRANE AND SOLUBLE FRACTIONS OF Giardia duodenalis TROPHOZOITES OF TWO BRAZILIAN AXENIC STRAINS
}

Semíramis GUIMARÃES(1), Maria Inês T. Leme SOGAYAR(1) \& Marcello FRANCO(2)

\begin{abstract}
SUMMARY
In the present study, we have analyzed by sodium docecyl sulphate - polyacrilamide gel electrophoresis (SDS-PAGE), immunoblotting and Concanavalin A blotting (Con A blotting) proteins of membrane fractions and soluble fractions obtained from Giardia duodenalis trophozoites of two axenic strains isolated in Brazil from a symptomatic (BTU-11) and an asymptomatic patient (BTU-10), as compared to the reference strain Portland 1. Both Brazilian strains showed a complex and homogeneous electrophoretic pattern of proteins, but some differences could be observed. Several glycoproteins were detected, particularly the proteins of 81,72 , $59 \mathrm{kDa}$ and the protein of $62 \mathrm{kDa}$ in the membrane proteins and cytosol, respectively. Many antigenic components were revealed by anti-Giardia rabbit IgG antibodies in the immunoblotting analysis. Among these components, the membrane protein of $32 \mathrm{kDa}$ and the cytosol protein of $30 \mathrm{kDa}$ could be related to giardin, as previously demonstrated.
\end{abstract}

KEYWORDS: Giardia duodenalis; Axenic strains; Trophozoites; Proteins; Glycoproteins; Antigens.

\section{INTRODUCTION}

Giardia duodenalis (syn. Giardia lamblia, Giardia intestinalis), an important worldwide intestinal protozoa is one of the most common nonviral causes of diarrhoea both in developed and underdeveloped countries. Nowadays, the infection may reach a prevalence of $2-7 \%$ in Western countries and of 20-60\% in developing countries ${ }^{22}$. About 200 million people in Asia, Africa and Latin America have symptomatic giardiasis and there are some 500000 new cases per year ${ }^{28}$.

Giardiasis has a range of clinical expression from asymptomatic cyst passage to a syndrome of chronic diarrhea, malabsorption, and weight loss. This clinical variability has been attributed to factors related to the parasite (mechanical, proteolytic, immunologic), host (diet, intestinal motility, nutritional and immunologic status) and host-parasite interactions (immune response and association with intestinal microflora). The specific pathogenic mechanisms of Giardia, the factors responsible for the conversion of an asymptomatic infection to a symptomatic one and their impact on the host-parasite relationship still need investigation. However, there is increasing evidence that a particular strain, or isolate, of Giardia may have a greater potential to cause disease in a particular host $^{22}$.

Considering that the composition and complexity of Giardia strains might be associated with aspects of the host-parasite relationship, characterization of trophozoites proteins from axenic strains have been conducted in order to expand the knowledge of this parasite and to detect differences between strains $s^{2,5,6,7,12,21,25}$. The proteins of trophozoites have been studied in terms of their localization and with respect to their nature and properties.

The great part of these investigations has been carried out in countries where giardiasis is not endemic. Moreover, there is increasing interest to conduct studies in attempting to learn more about strains isolated and axenized in endemic areas.

Thus, the aim of this study was to identify and characterize proteins of $G$. duodenalis trophozoites of two axenic strains isolated in Brazil from a symptomatic (BTU-11) and an asymptomatic patient (BTU-10), as compared to the reference strain Portland 1.

\section{MATERIAL AND METHODS}

Parasites and culture - Trophozoites of three axenic strains of $G$. duodenalis were studied. Two of them were isolated in Brazil, at the Giardiasis Laboratory (IB/UNESP) in Botucatu, São Paulo: BTU-10 from a 21 year-old asymptomatic male and BTU-11 from a 40 year-old symptomatic male presenting diarrhea, flatulence and abdominal cramps. Both strains were obtained from cysts recovered from patient's feces. The reference strain Portland 1 (P1), originally isolated by MEYER (1976) from a 36 year-old symptomatic female from Portland, Oregon (USA), was obtained from H. W. Pillai (Division of Geographic Medicine

(1) Departamento de Parasitologia, Instituto de Biociências, Universidade Estadual Paulista, UNESP, Botucatu, São Paulo, Brasil

(2) Departamento de Patologia, Escola Paulista de Medicina/Universidade Federal de São Paulo (Unifesp), São Paulo, SP Brasil

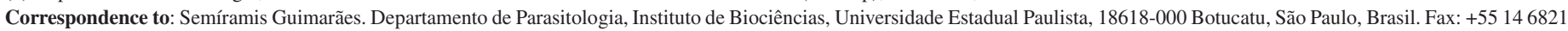
3744. e-mail: sgviana@ibb.unesp.br 
Tufts University, New England Medical Center, Boston, USA) and it was used as a standard strain. Trophozoites were grown axenically in TYI-S-33 (Trypticase, yeast extract, iron-serum) medium ${ }^{11}$.

Extraction of proteins from axenic cultures - Trophozoites harvested in log-phase growth within 72 to $96 \mathrm{~h}$ postinoculation, after chilling in wet ice for $15 \mathrm{~min}$, were washed four times in phosphate buffered saline (PBS) by centrifugation at $250 \mathrm{x} \mathrm{g}$ for $20 \mathrm{~min}$ at $4{ }^{\circ} \mathrm{C}$ and the pellet stored at $-60{ }^{\circ} \mathrm{C}$. Trophozoite masses were thawed at room temperature and processed according to the method described by MOSS et al. ${ }^{15}$. Briefly, each suspension $\left(2 \times 10^{8}\right.$ trophozoites) was treated with protease inhibitors [phenylmethylsulfonyl fluoride (PMSF, 1mM), $N$-tosyl-Lphenylalanine chlorometyl ketone (TPCK, $1 \mathrm{mM}$ ), $N$ - $\alpha$-p-tosyl-L-lysine chlorometyl ketone (TLCK, $1 \mathrm{mM}$ ), iodacetamide (IAA, 1mM)] and lysed by freeze-and-thaw three times. The lysates were centrifuged at 24,000 $\mathrm{x} \mathrm{g}$ for $30 \mathrm{~min}$ at $4{ }^{\circ} \mathrm{C}$ and fractionated into cytosol and membrane fractions. The supernatants were collected and labeled "water-soluble (WS) protein fractions", and stored at $-60^{\circ} \mathrm{C}$. The sediments containing the membranous material were centrifuged at $24,000 \mathrm{x}$ g for $30 \mathrm{~min}$ at 4 ${ }^{\circ} \mathrm{C}$. The supernatants were removed and the pellets were solubilized overnight in $8 \mathrm{M}$ urea-0.05 M Tris HCl-0.3 M KCl-0.2 mM EDTA, pH 8.0 , at $4{ }^{\circ} \mathrm{C}$. The suspensions were submitted to ultrasonic disruption with a Vibra cell ultrasonic processor (VCX-400) and the extracts were centrifuged at $24,000 \mathrm{x}$ g for $30 \mathrm{~min}$ at $4{ }^{\circ} \mathrm{C}$. The supernatants were collected, dialyzed and concentrated against $40 \mathrm{mM}$ Tris $\mathrm{HCl}-54 \mathrm{mM}$ boric acid-1 mM EDTA, pH 8.3. The samples were labeled "membranebound (MB) protein fractions" and stored at $-60{ }^{\circ} \mathrm{C}$ until required for use. The protein contents of water soluble (WS) and membrane-bound (MB) protein fractions were determined by the method of BRADFORD ${ }^{1}$.

Preparation of anti-Giardia IgG - Immune sera to Giardia were raised by immunizing rabbits according to GUIMARÃES et al. ${ }^{8}$. For each strain, two rabbits were immunized with four doses and the interval between each one was fifteen days. In the first dose, animals were given $5 \times 10^{6}$ whole trophozoites by intraperitoneal route; in the second dose, $5 \times 10^{6}$ freeze-and-thaw disrupted trophozoites emulsified in Freund's Complete Adjuvant (v/v) on the rabbit's back; in the third dose, $5 \times 10^{6}$ freeze-and-thaw disrupted trophozoites emulsified in Freund's Incomplete Adjuvant (v/v) on the haunch. The booster dose of $2 \times 10^{6}$ disrupted trophozoites in PBS was given subcutaneously in the pads. The animals were bled on day ten after the booster and the serum collected, aliquoted and stored at $-20{ }^{\circ} \mathrm{C}$.

To fractionate $\mathrm{IgG}$, each rabbit immune sera was applied to a protein A Sepharose affinity chromatography column. The bounded antiGiardia antibodies ( $\mathrm{IgG}$ ) were eluted with $0.1 \mathrm{M}$ glycine ( $\mathrm{pH} 2.5$ ), neutralized and collected in aliquots. Protein concentration was determined by absorbance at $280 \mathrm{~nm}$ and the $\mathrm{IgG}$ was dialyzed against PBS at $4{ }^{\circ} \mathrm{C}$.

Protein electrophoresis (SDS-PAGE) - WS and MB protein fractions from each strain were separated by SDS-PAGE, as described by LAEMMLI $^{13}$, using a $7-14 \%$ separating gel and a $3 \%$ stacking gel. The samples were solubilized in sample buffer (1\% SDS-128 mM 2mercaptoethanol- $10 \%$ glycerol- $0.05 \%$ bromophenol blue-500 mM Tris $\mathrm{HCl}, \mathrm{pH}$ 6.8), boiled for $3 \mathrm{~min}$ and either $4 \mu \mathrm{g}$ (silver staining) or $30 \mu \mathrm{g}$ (immunoblotting and Con-A blotting) were applied to the gels. After electrophoresis, gels were either stained with ammoniacal silver solution ${ }^{27}$ or prepared for immunoblotting and Con-A blotting as described below. Molecular weight markers were used.

Antigenic analysis by immunoblotting - For immunoblotting assays, protein fractions (WS and MB) separated by SDS-PAGE were transferred to nitrocellulose $(0.45 \mu \mathrm{m})$ according to TOWBIN et al. ${ }^{23}$. After the transfer, the nitrocellulose sheets were blocked with 5\% skim milk in 10 $\mathrm{mM}$ Tris saline $(\mathrm{pH} 7.4)$ for $2 \mathrm{~h}$ at room temperature. The strips were incubated overnight at $4{ }^{\circ} \mathrm{C}$ with specific rabbit anti-Giardia $\operatorname{IgG}(1: 100)$ in Tris saline with $1 \%$ skim milk. Negative controls were included in all reactions. After incubation, the sheets were washed four times with Tris saline and exposed to a 1:4000 dilution of horseradish peroxidaseconjugated goat anti-rabbit $\operatorname{IgG}$ for $2 \mathrm{~h}$ at room temperature. The blot was then rinsed and the color reaction was developed using $1 \mathrm{mg} / \mathrm{ml}$ of 3,3'-diaminobenzidine tetrahydrochloride and $0.5 \mathrm{mg} / \mathrm{ml}$ of 4-chloro, $1-\alpha$-naphthol in Tris saline containing $0.1 \%$ hydrogen peroxide. The reaction was stopped by washing the strips in distilled water.

Concanavalin-A (Con-A) blot - Glycoproteins binding Con-A were detected on nitrocellulose sheets by a modification of the method of HAWKES $^{9}$. Water-soluble (WS) and membrane-bound (MB) protein fractions were fractionated by SDS-PAGE and transferred to nitrocellulose as described above. The sheets were washed in PBS- $0.3 \%$ Tween 20 (PBS-TW) and incubated overnight at $4{ }^{\circ} \mathrm{C}$ with PBS-TW containing $50 \mu \mathrm{g} / \mathrm{ml}$ Con-A. The next day the sheets were washed and incubated with a solution containing $50 \mu \mathrm{g} / \mathrm{ml}$ horseradish in PBS-TW. After $1 \mathrm{~h}$ at room temperature, the sheets were washed twice, $10 \mathrm{~min}$ each in PBS-TW, followed by two 10 min washes in PBS alone. The sheets were then exposed to the substrate solution as described above for immunoblotting reaction. To confirm the specific reaction of glycoproteins with Con-A, some strips were incubated with a solution of PBS-TW and others were incubated with a solution containing ConA and a competing sugar, 0.1M $\alpha$-D-methylmannoside.

Molecular masses determination - Molecular masses of fractionated proteins were determined by analysis in Image Master VDS (Pharmacia).

Reagents - Electrophoresis reagents, blot reagents, molecular weight marker and protease inhibitors were purchased from Sigma Chemicals Corporation Ltd.

\section{RESULTS}

Figure 1 shows the SDS-PAGE profile of membrane-bound (Fig. 1A) and water-soluble (Fig. 1B) protein fractions of two Brazilian strains (BTU-10 and BTU-11) and the reference strain P-1. The membrane fractions of all strains revealed a large number (26-30) of bands with molecular masses ranging from 182 to $10 \mathrm{kDa}$ (Fig. 1A). The protein patterns were similar and many bands were common to the three strains. However, heterogeneity could be detected among some proteins into the groups with molecular masses between 182 to $64 \mathrm{kDa}, 55$ to $49 \mathrm{kDa}$ and 38 to $25 \mathrm{kDa}$. The bands below $25 \mathrm{kDa}$ were faint, mainly in the pattern of strain BTU-11. The band at approximately $97 \mathrm{kDa}$ was striking in the three strains. The profile of soluble fractions (Fig. 1B) were composed of approximately 16 bands with molecular masses ranging from 122 to $10 \mathrm{kDa}$. The protein bands detected were for the most part homogeneous. All strains profiles revealed a prominent component having a molecular mass of $38 \mathrm{kDa}$. 




Fig. 1 - SDS-PAGE (7-14\% gradient and silver stain) of membrane-bound (A) and watersoluble (B) protein fractions of G. duodenalis trophozoites. The strains were loaded as follows: BTU-10 (lane 1), BTU-11 (lane 2) and P1 (lane 3). Molecular mass markers are shown on the left in kilodaltons $(\mathrm{kDa})$.

Figure 2 shows the Con-A blot pattern of protein fractions of the three strains. Many of the membrane components of the three strains reacted with the lectin Con-A and revealed glycoprotein bands at molecular masses between 123 to $32 \mathrm{kDa}$ (Fig. 2A). Although the strains were similar, some differences could be identified. The profile of BTU10 glycoproteins showed faint bands. However, strains P-1 and BTU-11 revealed prominent components such as the bands at approximately 81 $\mathrm{kDa}(\mathrm{P}-1$ and BTU-11), $72 \mathrm{kDa}$ (P-1 and BTU-11) and $59 \mathrm{kDa}(\mathrm{P}-1)$. The most marked component was the band at $81 \mathrm{kDa}$ (Fig. 2A). More homogeneous profiles could be identified in the soluble fraction when Con-A was the probe (Fig. 2 B). One sized $62 \mathrm{kDa}$ band was the most consistent component recognized in all strains (Fig. 2 B).

Antigens were recognized among the membrane-bound and watersoluble protein fractions of all three strains, using immunoblot technique and homologous rabbit anti-Giardia IgG (Fig. 3). The antigenic profiles of membrane fractions showed bands ranging in molecular masses from 210 to $32 \mathrm{kDa}$; the majority of the bands were in the range between 210 to $59 \mathrm{kDa}$ (Fig. 3A). Many bands in the $210-116 \mathrm{kDa}$ region were common for all strains. These included the bands at the 210, 188, 167, 145, 134, 124 and $116 \mathrm{kDa}$. An evident band at $32 \mathrm{kDa}$ was recognized in all strains. Heterogeneity was seen among antigens identified in the 97-50 kDa range of $\mathrm{P}-1$ and $\mathrm{BTU}-11$ protein fraction in comparison to strain BTU-10, demonstrating differences in this region (Fig. 3A). Fewer antigens were found in the soluble protein fractions of the three strains (Fig. 3B). The antigenic profiles revealed common antigens for the strains, but distinct differences were observed such as the antigens of 92, 66, 52 and $30 \mathrm{kDa}$ in the strain BTU-10 and the components of 64 and $62 \mathrm{kDa}$ in the strains BTU-11 and P-1 (Fig. 3B).

\section{DISCUSSION}

Biochemical and antigenic analysis of trophozoite proteins are an important step in expanding the knowledge on Giardia strains and to detect differences among them.
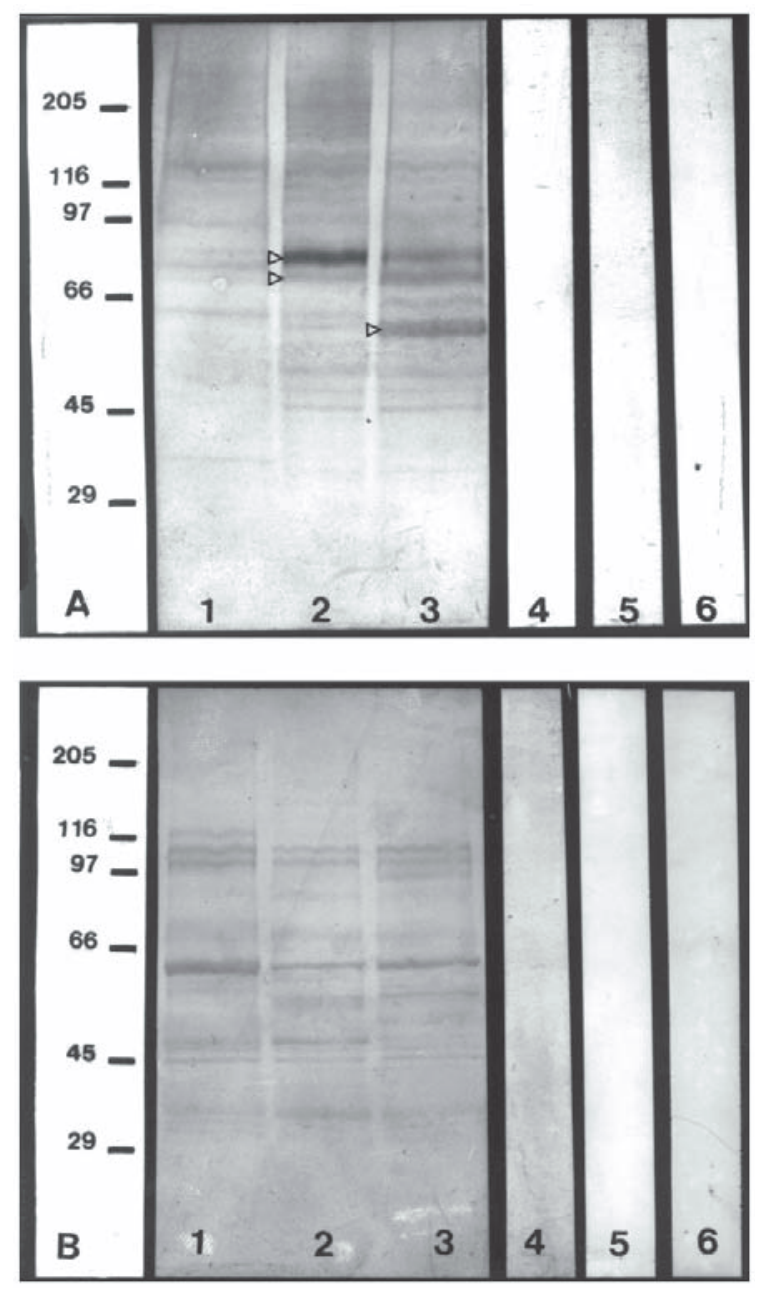

Fig. 2 - Concanavalin A (Con-A) blot of membrane-bound (A) and water-soluble (B) protein fractions of G. duodenalis trophozoites. The strains were loaded as follows: BTU-10 (strips 1and 4), BTU-11 (strips 2 and 5) and P1 (strips 3 and 6). Strips 1, 2 and 3 were incubated with a solution containing Con-A and strips 3, 4 and 6 were incubated with a solution containing Con-A and a competing sugar, $0.1 \mathrm{M} \alpha$-D-methylmannoside. Molecular mass markers are shown on the left in kilodaltons $(\mathrm{kDa})$. Arrows $(\triangleright)$ indicate the bands of $81 \mathrm{kDa}$ (Fig. 2A), $72 \mathrm{kDa}$ (Fig. 2A) and $59 \mathrm{kDa}$ (Fig. 2B).

In the present study, membrane and soluble fraction associated proteins of trophozoites from two Brazilian axenic strains (BTU-10 and BTU-11) and the reference strain Portland 1 (P-1) were examined. We have demonstrated multiple proteins, glycoproteins and antigens in membranes as well as in soluble fractions of trophozoites from the three strains. Overall, the strains BTU-10 and BTU-11 showed a complex and homogeneous profiles of proteins, glycoproteins and antigens. In addition to some similarity among the strains, differences could be detected mainly in membrane-bound protein fractions. According to DEN HOLLANDER et $a l .{ }^{4}$, differences among Giardia isolates can be most pronounced in the membrane fractions, although differences may exist in other fractions as well.

The complexity of protein fractions of Giardia duodenalis trophozoites has been reported by several authors $2,5,6,7,12,21,25$. In our study, 

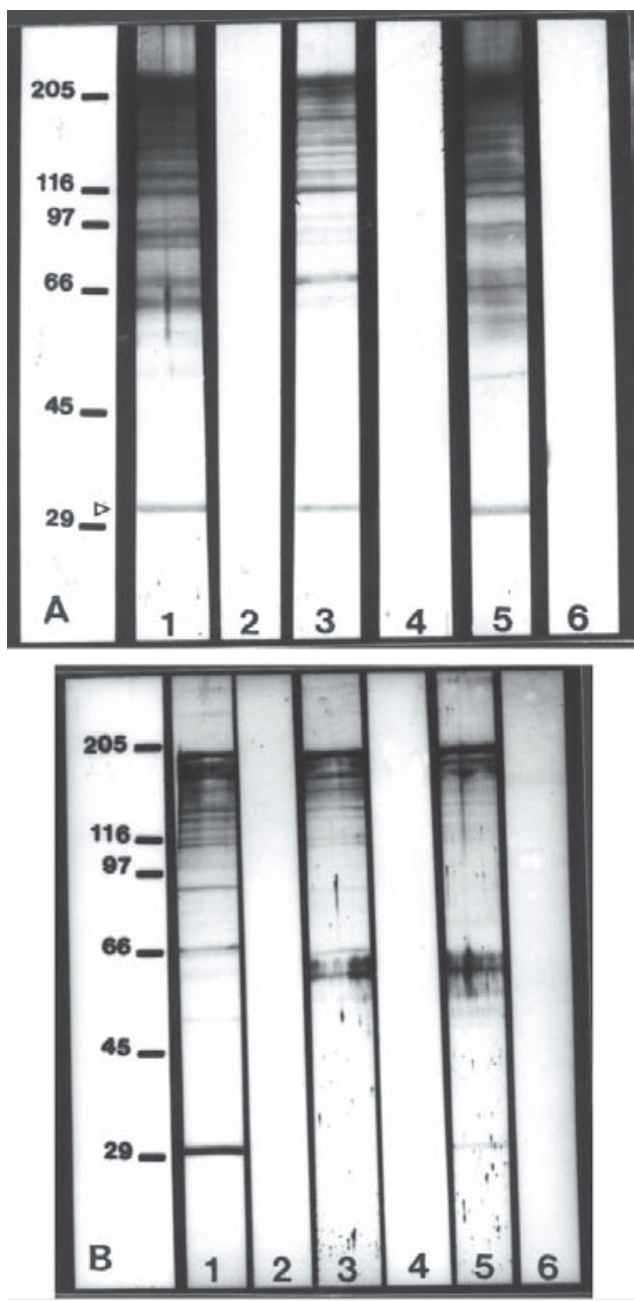

Fig. 3 - Immunoblotting of membrane-bound (A) and water-soluble (B) protein fractions of G. duodenalis trophozoites. The strains were loaded as follows: BTU-10 (strips 1 and 2), BTU-11 (strips 3 and 4) and P1 (strips 5 and 6). Strips 1, 3 and 5 reacted with rabbit anti-IgG raised against the strains BTU-10, BTU-11 and P1, respectively. Strips 2, 4 and 6 were exposed to negative rabbit serum. Molecular mass markers are shown on the left in kilodaltons $(\mathrm{kDa})$. Arrow $(\triangleright)$ indicates the band of $32 \mathrm{kDa}$ (Fig. 3A).

the analysis of electrophoretic protein patterns of the Brazilian strains (BTU-10 and BTU-11), similarity to the reference strain P-1 revealed complex profiles with the detection of multiple bands with molecular masses ranging from 182 to $10 \mathrm{kDa}$ and 122 to $10 \mathrm{kDa}$ in membrane fractions and soluble fractions, respectively. In general, the electrophoretic patterns reported are complex and homogeneous, with the detection of multiple protein bands ranging from 140 to $10 \mathrm{kDa}^{21}, 122$ to $10 \mathrm{kDa}^{2}$ or 250 to $14 \mathrm{kDa}^{24}$. The overall homogeneity of the protein patterns is

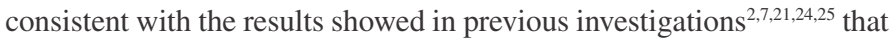
employed other strains. Heterogeneity has been observed in the 20-25 $\mathrm{kDa}$ and $50-56 \mathrm{kDa}$ regions ${ }^{7,26}$.

Glycoproteins were identified among membrane-bound and watersoluble protein fractions in trophozoites of the three strains. According to JACOBSON \& DOYLE ${ }^{10}$, all parasites have carbohydrates on their surfaces, as part of their cytoskeletons or in their internal structures. Sugars such as D-mannose, D-glucose, N-acetyl-D-glucosamine, Lfucose, D-galactose and N-acetyl-D-galactosamine have been detected in trophozoites of the reference strain WB by other investigators ${ }^{18}$. Based on the specific binding of Con-A to the proteins, our study could indicate that mannose and glucose are part of the sugar composition in $G$. duodenalis trophozoites of the strains isolated and axenized in Brazil and in the reference strain P-1. Con-A blot revealed a major glycoprotein of $81 \mathrm{kDa}$ found on the membrane-bound protein fractions of the strains BTU-11 and P-1, both obtained from a symptomatic patient. EINFELD \& STIBBS $^{6}$, identified and characterized a glycoprotein with molecular mass of $82 \mathrm{kDa}$ that was detected on the trophozoite surface of strains isolated from symptomatic patients in USA (P-1), Afghanistan (WB) Puerto Rico (LT) and from an asymptomatic carrier from Ecuador (RS).

Antigenic components with molecular masses ranging from 295 to $32 \mathrm{kDa}$ and 198 to $30 \mathrm{kDa}$ were detected among membrane and soluble fractions, respectively. It is important to emphasize that the proteins of $32 \mathrm{kDa}$ and $30 \mathrm{kDa}$ detected in membranes and soluble fractions, respectively. The present study and early investigations have described a variety of antigenic proteins of Giardia duodenalis trophozoites like as those of $88,82,66,62,52,38$ and $30-34 \mathrm{kDa}^{2,5,6,7,25,26}$. Among these antigens, the protein of $32 \mathrm{kDa}$ have been recognized as an important component in a variety of strains ${ }^{2,7,25,26}$. CROSSLEY \& HOLBERTON ${ }^{3}$ detected a group of proteins associated with microtubules of ventral disc in the $30 \mathrm{kDa}$ range that these authors termed giardins. In a further study, these components were defined as a group of proteins in the 29 to $38 \mathrm{kDa}$ range ${ }^{19}$. WENMAN et al. ${ }^{26}$, using immunoelectron microscopy, found the $32 \mathrm{kDa}$ antigen on the trophozoite ventral disc and on the membrane. It is possible that the $32 \mathrm{kDa}$ and $30 \mathrm{kDa}$ components that we reported here may be giardin.

The great part of antigens recognized among the protein fractions were common to Brazilian strains and to reference strain Portland. This observation confirms the presence of common components among different strains. In relation to some heterogeneity in protein patterns and antigens among the three strains, this fact suggests that certain components can be characteristic of a particular strain.

Another point to be considered is that some proteins, glycoproteins and antigens detected in our study showed similar or close molecular masses to those of proteins associated with plasma membrane identified in early investigations $\mathrm{s}^{5,6,16,17,25}$. In the present study, the method employed to obtain subcellular fractions of trophozoites did not allow the fractionation of plasma membrane proteins from those bound to the internal membranes. So, we did not analyse the surface proteins but those associated with all membranes of the trophozoites. Therefore, according to DEN HOLLANDER et al. ${ }^{4}$, as Giardia spp have few internal demonstrated membrane-bound organelles, the membrane differences among isolates may involve polypeptides of plasma membrane.

Our attempt to identify and characterize proteins of G. duodenalis allowed us to demonstrated multiple glycoproteins and antigens in membranes and soluble fractions of trophozoites of two Brazilian axenic strains. In Brazil, no previous studies have, to our knowledge, analysed the antigenic and glycoproteic profiles of autochtonous strains. ROCHA et $a l .{ }^{20}$ reported the characterization of a strain obtained from an asymptomatic patient in Minas Gerais. Electrophoretic and isoenzyme 


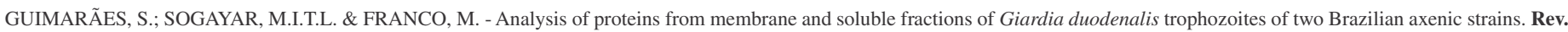
Inst. Med. trop. S. Paulo, 44(5):239-244, 2002.

patterns of protein extracts revealed differences between the strain BHRF92 and the reference strain Portland.

Despite the importance of G. duodenalis in developing countries, little is known about the biochemical and antigenic characteristics of strains isolated in our country. The present study is a preliminary step in the characterization of autochtonous strains isolated from individuals with asymptomatic giardiasis and from symptomatic patients. Our results hold the perspective for the understanding about the proteins, glycoproteins and antigens of $G$. duodenalis trophozoites of axenic strains isolated in an endemic area.

\section{RESUMO}

\section{Análise de proteínas de frações de membranas e de frações solúveis de trofozoítos de duas cepas de Giardia duodenalis, isoladas e axenizadas no Brasil}

Foi realizada a análise de algumas características bioquímicas e antigênicas de duas cepas axênicas de Giardia duodenalis, isoladas em Botucatu, a partir de cistos obtidos de paciente sintomático (BTU-11) e assintomático (BTU-10), tendo por referência a cepa padrão Portland 1 (P-1), isolada e axenizada nos Estados Unidos.

Preparações contendo proteínas de membranas e proteínas solúveis (citosol) de cada cepa foram empregadas na eletroforese das proteínas em gel de poliacrilamida (SDS-PAGE), na análise de glicoproteínas pela técnica de Con A blot e na análise antigênica pela técnica de "Immunoblotting".

Na análise do perfil eletroforético os padrões de bandas de proteínas das cepas BTU-10 e BTU-11 foram complexos e na maior parte homogêneos; algumas diferenças foram detectadas entre as proteínas de membranas.

Várias glicoproteínas foram demonstradas, destacando-se as de 81, $72,59 \mathrm{kDa}$ e a glicoproteína de $62 \mathrm{kDa}$, detectadas nas preparações de proteínas de membranas e proteínas solúveis, respectivamente. Entre estas glicoproteínas, a de $81 \mathrm{kDa}$ foi detectada apenas entre as proteínas de membranas das cepas BTU-11 e P-1, isoladas de casos sintomáticos.

Vários componentes antigênicos foram reconhecidos por anticorpos IgG de coelho pela técnica de "Immunoblotting". Entre estes componentes, as proteínas de $32 \mathrm{kDa}$, entre as proteínas de membranas e a de $30 \mathrm{kDa}$, entre as proteínas solúveis, parecem tratar-se de proteínas já caracterizadas como "giardinas".

O presente trabalho possibilitou detectar glicoproteínas, proteínas e antígenos em trofozoítos de duas cepas autóctones de G. duodenalis. De modo geral, as análises dos perfis eletroforético e glicoproteico e do "immunoblotting" demonstraram similaridade entre as cepas.

\section{ACKNOWLEDGMENTS}

This work was supported by Fundação de Amparo à Pesquisa do Estado de São Paulo-FAPESP (Grant no. 94/2946-6).

\section{REFERENCES}

1. BRADFORD, M.M. - A rapid and sensitive method for the quantitation of microgram quantities of protein utilizing the principle of protein-dye bindings. Analyt. Biochem., 72: 248-254, 1976.

2. CAPON, A.G.; UPCROFT, J.A.; BOREHAM, P.F.L.; COTTIS, L. \& BUNDESEN, P.G. - Similarities of Giardia antigens derived from human and animal sources. Int. J. Parasit., 19: 91-98, 1989.

3. CROSSLEY, R. \& HOLBERTON, D.V. - Characterization of proteins from cytoskeleton of Giardia lamblia. J. Cell Sci., 59: 81-103, 1983.

4. DEN HOLLANDER, N.; RILLEY, D. \& BEFFUS, D. - Immunology of giardiasis. Parasit. today, 4: 124-131, 1988.

5. EDSON, C.M.; FARTHING, M.J.G.; THORLEY-LAWSON, D.A. \& KEUSCH, G.T. An 88,000-Mr Giardia lamblia surface protein which is immunogenic in humans. Infect. Immun., 54: 621-625, 1986.

6. EINFELD, D.A. \& STIBBS, H.H. - Identification and characterization of a major surface antigen of Giardia lamblia. Infect. Immun., 46: 377-383, 1984.

7. FORREST, M.; ISSAC-RENTON, J. \& BOWIE, W. - Immunoblot patterns of Giardia duodenalis isolates from different hosts and geographical locations. Canad. J. Microbiol., 36: 42-46, 1990.

8. GUIMARÃES, S.; URDANETA, H.; SILVA, E.F. \& TAVARES, C.A.P. - Entamoeba histolytica: antigenic characterization of axenic strains from Brazil. Rev. Inst. Med. trop. S. Paulo, 33: 6-11, 1991.

9. HAWKES, R. - Identification of concanavalin-A-binding proteins after sodium dodecyl sulfate-gel electrophoresis and protein blotting. Analyt. Biochem., 123: 143-146, 1982

10. JACOBSON, R.L. \& DOYLE, R.J. - Lectin-parasite interactions. Parasit. today, 12: 55-60, 1996.

11. KEISTER, D.B. - Axenic culture of Giardia lamblia in TYI-S-33 medium supplemented with bile. Trans. roy. Soc. trop. Med. Hyg., 77: 487-488, 1983.

12. KUMKUM KHANNA, R.; KHULLER, M.; MEHTA, S. \& VINAYAK, V.K. - Plasma membrane associated antigens of trophozoites of axenic Giardia lamblia. Trans. roy. Soc. trop. Med. Hyg., 82: 439-444, 1988.

13. LAEMMLI, U.K. - Cleavage of structural protein during the assembly of the head bacteriophage T4. Nature (Lond.), 277: 680-685, 1970.

14. MEYER, E.A. - Giardia lamblia: isolation and axenic cultivation. Exp. Parasit., 39: 101-105, 1976.

15. MOSS, D.M.; MATHEWS, H.M.; VISVESVARA, G.S.; DICKERSON, J.W. \& WALKER, E.M. - Antigenic variation of Giardia lamblia in the feces of Mongolian gerbils. J. clin. Microbiol., 28: 254-257, 1990.

16. NASH, T.E.; GILLIN, F.D. \& SMITH, P.D. - Excretory-secretory products of Giardia lamblia. J. Immunol., 131: 2004-2010, 1983.

17. NASH, T.E. \& AGGARWAL, A. - Cytotoxicity of monoclonal antibodies to a subset of Giardia isolates. J. Immunol., 136: 2628-2632, 1986.

18. ORTEGA-BARRIA, E.; WARD, H.D.; EVANS, J.E. \& PEREIRA, M.E.A. - N-acetylD-glucosamine is present in cysts and trophozoites of Giardia lamblia and serves as receptor for wheatgerm agglutinin. Molec. Biochem. Parasit., 43: 151-165, 1990.

19. PEATTIE, D.M.; ALONSO, R.A.; HEIN, A. \& CAULFIELD, J.P. - Ultrastructural localization of giardins to the edges of disk microribbons of Giardia lamblia and the nucleotide and deduced protein sequence of alpha giardin. J. Cell Biol., 109: 2323 $2335,1989$. 


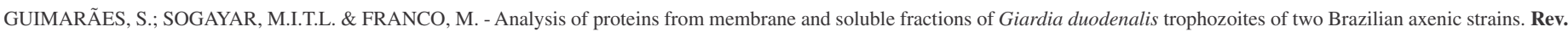
Inst. Med. trop. S. Paulo, 44(5):239-244, 2002.

20. ROCHA, M.O.; TOLEDO, V.P.C.P.; MELLO, R.T. et al. - Giardia lamblia: isolation, axenization and characterization of a strain from an asymptomatic patient from Belo Horizonte, MG, Brazil. Mem. Inst. Oswaldo Cruz, 90: 43-44, 1995.

21. SMITH, P.D.; GILLIN, F.D.; KAUSHAL, N.A. \& NASH, T.E. - Antigenic analysis of Giardia lamblia from Afghanistan, Puerto Rico, Ecuador, and Oregon. Infect. Immun., 36: 714-719, 1982.

22. THOMPSON, R.C.A.; REYNOLDSON, J.A. \& MENDIS, A.H.W. - Giardia and giardiasis. Advanc. Parasit., 32: 71-160, 1993.

23. TOWBIN, H.; STAEHELIN, T. \& GORDON, J. - Electrophoretic transfer of proteins from polyacrylamide gels to nitrocellulose sheets: procedure and some applications. Proc. nat. Acad. Sci. (Wash.), 76: 4350-4354, 1979.

24. UDEZULU, I.A.; VISVESVARA, G.S.; MOSS, D.M. \& LEITCH, G.J. - Isolation of two Giardia lamblia (WB strain) clones with distinct surface protein and antigenic profiles and differing infectivity and virulence. Infect. Immun., 60: 2274-2280, 1992.
25. WENMAN, W.M.; MEUSER, R.U. \& WALLIS, P.M. - Antigenic analysis of Giardia duodenalis strains isolated in Alberta. Canad. J. Microbiol., 32: 926-929, 1986.

26. WENMAN, W.M.; MEUSER, R.U.; NYUGEN, Q. et al. - Characterization of an immunodominant Giardia lamblia protein antigen related to alpha giardin. Parasit. Res., 79: 587-592, 1993.

27. WRAY, W.; BOULIKAS, T.; WRAY, V.P. \& HANCOCK, R. - Silver staining of proteins in polyacrylamide gels. Anal. Biochem., 118: 197-203, 1981.

28. WHO - The World Health Report1996. Geneva, World Health Organization, 1996.

Received: 21 March 2002

Accepted: 11 July 2002 